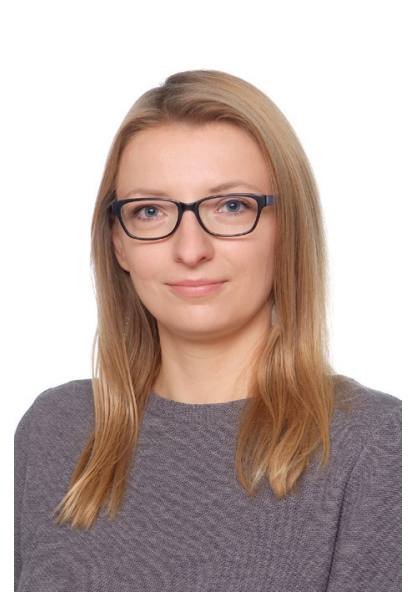

Žydrūnẻ Šalaviejūtè - filologijos krypties doktorantè

Moksliniai interesai: leksinè semantika, leksikografija,

kognityvinè lingvistika

El.paštas: z.salaviejute@gmail.com

Žydrūnè Šalaviejūtè - PhD student of Philology

Research interests: lexical semantics, lexicography, cognitive linguistics

E-mail: z.salaviejute@gmail.com

\title{
Žydrūnè Šalaviejūtè
}

Klaipedos universitetas

\section{LIETUVIŲ KALBOS ZOONIMAI: KARVÉS, JAUČIO, VERŠIO PAVADINIMAI IR JŲ MOTYVACIJA}

\begin{abstract}
Anotacija
Straipsnyje kompleksiškai analizuojami lietuvių kalbos karvès, jaučio, veršio pavadinimai, siekiant nustatyti, kokius konceptualiuosius gyvūnų požymius padeda išryškinti semasiologiniai ir onomasiologiniai leksikos tyrimai. Pagrindinis empirinès medžiagos šaltinis - LKŽe. Kompleksinė semasiologinè ir onomasiologinè leksemų analizè rodo, kad kalbos sistema fiksuoja labai įvairius karvès, jaučio, veršio konceptualiuosius požymius. Aptariamų gyvulių hierarchijos viršūnèje yra karvè. Iš kalbos sistemos ryškẻjanti kategorizacija atskleidžia antropocentrini gyvulių vertinimą. PAGRINDINIAI ŽODŽIAI: semasiologija, onomasiologija, zoonimai, motyvacijos modelis, motyvacijos modelių tipai.
\end{abstract}

\section{Abstract}

Methodological practice is based on complex linguistic research when semasiological and onomasiological aspects are combined. The article analyses the Lithuanian words for cow, bull and calf, in order to determine what conceptual features of animals semasiological and onomasiological lexical studies help to highlight. The main source of empirical material is the dictionary of the Lithuanian language. The analysis of complex semasiological and onomasiological lexemes shows that the language system identifies various conceptual features of cow, bull and calf. At the top of the animal hierarchy is the cow. The categorisation that emerges from the language system reflects the anthropocentric evaluation of the animals discussed.

KEY WORDS: semasiology, onomasiology, zoonyms, model of motivation, types of models of motivation. 
Ivadas

Lietuvių kalbotyroje tirta gyvūnų pavadinimų kilmè, paplitimas, kalbinio pasaulèvaizdžio raiška zooniminiuose palyginimuose ir frazeologijoje (Šalaviejūtè 2018, 28-29). Iš zoonimams skirtų darbų matyti, kad gyvūnų pavadinimai vartojami įvardijant žmogaus būdo savybes, jị supančią aplinką, artefaktus, įvairius gyvosios ir negyvosios gamtos, erdvès objektus bei kitas realijas ${ }^{1}$. Neabejotina, kad GYVŪNO makrokonceptas priklauso bazinių konceptų grupei.

Straipsnio objektas - lietuvių kalbos karvès, jaučio, veršio pavadinimai pasirinktas neatsitiktinai. Kompleksinès karvės, jaučio, veršio pavadinimų analizès, apimančios jų sisteminių santykių, nominacijos ir motyvacijos sritis, lietuvių kalbotyroje nèra.

Šiame straipsnyje kompleksiškai analizuojami karvès, jaučio, veršio pavadinimai, siekiant nustatyti, kokius konceptualiuosius gyvūnų požymius padeda išryškinti semasiologiniai ir onomasiologiniai leksikos tyrimai.

Pagrindinis empirinès medžiagos šaltinis - „Lietuvių kalbos žodynas“ $(\mathrm{LKŽe})^{2}$. Remiamasi kompleksinio lingvistinio tyrimo metodologine praktika, kai vienos teminés grupès (TG) nariai tiriami onomasiologiniu ir semasiologiniu aspektais ${ }^{3}$. Onomasiologinei analizei atlikti remiamasi Jūratès Lubienès monografijoje (Lubiené 2015) taikoma metodika, t. y. empirinė medžiaga sisteminama pagal: nominacijos tipus, būdus ${ }^{4}$, leksinius motyvatorius, motyvacijos požymius, motyvacijos modelius ir jų tipus. Siekiant išryškinti motyvacijos požymiu raiškos įvairumą, sistemingumą, taikyta keliapakope abstrakcijos lygmenų analizè:

1) žemiausioje abstrakcijos lygmenų pakopoje nustatyti leksiniai motyvatoriai (LM);

2) aukštesnëje abstrakcijos lygmenu pakopoje nustatyti semantiniai motyvacijos modeliai (MM);

3) aukščiausioje abstrakcijos lygmenų pakopoje nustatyti motyvacijos modelių tipai (MMT).

Tai universali savybè, būdinga ir kitoms kalboms (̌̌r. Alinei 2005).

2 Medžiaga papildyta „Dabartinès lietuvių kalbos žodyno“ (DŽe), „Sinonimų žodyno“ (SŽe), „Sisteminio lietuvių kalbos žodyno“ (SistŽe) duomenimis.

3 Toks semantinių tyrimų aspektas dar vadinamas nominacijos teorija. Semasiologijos ir onomasiologijos sąveika padeda atskleisti, kas ir kaip yra pavadinama, kitaip tariant, nustatyti ryši tarp kalbine forma išreikšto koncepto formos ir turinio.

4 Pavadinimų daryba detaliau, t. y. atsižvelgiant ị jų nominacijos rūšis ir priemones, šiame straipsnyje neaptariama. 
Semasiologinis tyrimo aspektas ir jo rezultatai

Visų pirma iškyla uždavinys nustatyti, kiek lietuvių kalbos sistemoje yra vieno gyvulio (mokslo kalboje - lo. Bos taurus arba lie. naminis jautis) pavadinimų. Remiantis tirtų leksikografijos šaltinių duomenimis, galima teigti, kad tiriamajai grupei (TG) priklauso apie pusantro šimto leksemų (įskaitant formaliuosius variantus).

Ištyrus sisteminius (hiperoniminius, sinoniminius, darybinius) santykius ir semantinius ryšius nustatyta, kad bendro hiperonimo aptariamam gyvuliui pavadinti lietuvių kalbos sistemoje (ne mokslo kalboje) nėra. TG branduoli sudaro trys ekvonimai: patelè (kárvè), patinas (jáutis) ir ja uniklis (veřšis). Ju semantiniai ryšiai, nustatyti pagal definicijas, išryškina du konceptualiuosius diferencinius požymius: lytį ir amžių.

Nustatyta, kad šie trys ekvonimai turi: formaliųjų variantų, darybinių ir leksinių sinonimų. Gausiausią darybinių ir leksinių sinonimų grupę sudaro karvės (55 procentai), kiek mažesnes jaučio (30 procentų) ir veršio (15 procentų) pavadinimai.

Onomasiologinis tyrimo aspektas ir jo rezultatai

Nustatyta, kad lietuvių kalbos karvės, jaučio, veršio pavadinimų onomasiologinę sistemą sudaro trys aukščiausiojo abstrakcijos lygmens MMT: deskriptyvusis (70 procentų), komparatyvusis (20 procentų), funkcinis (10 procentų).

Deskriptyvusis MMT remiasi kokybiniu (kvalitatyvumo) principu ir apima konceptus pagal ontologini KAŽKAS yra TOKS principą (plg. Zhabotynska 2010, 81-82). Šiam MMT priklauso tokios leksemos, kurių leksiniai motyvatoriai (LM) eksplicitiškai apibūdina išorines arba vidines gyvulio savybes (Lubienė 2015, 78-79). Nustatyta, kad lietuvių kalbos karvès, jaučio, veršio pavadinimuc deskriptyvuiji MMT sudaro trys MM: koloratyvusis (motyvacijos pagrindą sudaro rega suvokiamas konceptualusis spalvos požymis), akustinis (motyvacijos pagrindą sudaro klausa suvokiamas konceptualusis garso požymis), morfologinis (motyvacijos pagrindą sudaro konceptualusis gyvulio išorinès arba vidinès kūno sandaros požymis).

Komparatyvusis MMT remiasi kognityviniu panašumo, lyginimo principu ir apima konceptus pagal ontologinį KAŽKAS siejama su KAŽKUO principą (plg. Zhabotynska 2010, 83-84). Šiam MMT priklauso leksemos, kurių LM implicitiškai apibūdina išorines arba vidines gyvulio savybes (Lubienè 2015, 128). Nustatyta, kad ši MMT sudaro trys MM: zooniminis (motyvacijos pagrindą sudaro konceptualusis panašumo ar lyginimo su gyvūnu požymis), negyvosios gamtos (motyvacijos pagrindą sudaro konceptualusis gyvulio kūno savybių lyginimo su 
negyvosios gamtos realijomis požymis), artefaktinis (motyvacijos pagrindą sudaro gyvulio kūno savybių ar elgesio gretinimas su įvairiais artefaktais).

Funkcinis MMT remiasi kognityviniu veiksmo, elgesio principu ir apima konceptus pagal ontologinį KAŽKAS veikia / elgiasi TAIP principą (plg. Zhabotynska 2010, 82). Tai toks MMT, kuriam priklausančių pavadinimų LM remiasi atliekamo veiksmo principu, t. y. eksplicitiškai apibūdina gyvūno paskirti arba jo (su juo) atliekamą veiksmą, elgesi.

Norint nustatyti, koks santykis yra tarp motyvuotų ir nemotyvuotų pavadinimų, atrodo, kad metodiškai patogiau yra žvelgti i pavadinimus pagal semantikos ryšius. Todẻl aptariamojo gyvulio pavadinimų onomasiologinè struktūra straipsnyje aprašoma suskirsčius juos ị smulkesnes TG pagal karvès, jaučio ir veršio pavadinimus. Stengiamasi atkreipti dèmesị i jų ryškiausius konceptualiuosius diferencinius ir bendruosius požymius.

\section{Karvès pavadinimai}

Žvelgiant ị karvès pavadinimus sinchroniškai, jie yra dviejų nominacijos tipų: nemotyvuotosios ir motyvuotosios nominacijos.

1.1. Nemotyvuotosios nominacijos tipui priklauso invariantinès leksemos kárve, telyčià ${ }^{5}$, lietuvių kalbos sistemoje neprigijęs latvizmas gotina ${ }^{6}$, žinomas iš Simono Daukanto raštų (LKŽe).

Leksema kárvè - karvès pavadinimų TG dominantè, tai - 'stambus raguotas gyvulys, laikomas pienui ir mėsaï (LKŽe, DŽe). Pagal patekimą i kalbos sistemą kárvė yra vidinès nominacijos būdo leksema. Sinchroniniu požiūriu pavadinimas yra neskaidrios motyvacijos, tačiau diachroninių (etimologinių) tyrimų rezultatai padeda nustatyti senuosius motyvacijos požymius ${ }^{7}$. Etimologinė leksemos kárve motyvacija - problemiška. Saulius Ambrazas yra apibendrinęs, kad lie. kárve galejo kilti iš ide. būdvardžio, reiškusio 'raguotas', kuris žymèjo tik raguotus gyvulius: lo. cornū 'ragas' $\rightarrow$ lo. cervus 'elnias' $\rightarrow$ *kārva- 'raguotas' $\rightarrow$ lie. karvè, sl. *korva 'karvë', pr. curwis 'jautis' (Ambrazas 2010, 105-106). Remiantis diachroninių tyrimų rezultatais, senoji leksemos kárvẻ motyvacija galètų priklausyti deskriptyviajam MMT: 'ragas' $\rightarrow$ 'gyvulys su ragais' $\rightarrow$ ('raguotis') $\rightarrow$ 'karvë8.

Problemiška nustatyti nominacijos tipą, greičiausiai tai yra hibridinis priesagos skolinys iš slavų kalbų (plg. Smetonienè 2018, 249-250).

6 Senąii ide. 'raguoto galvijo' pavadinimą iš baltų kalbų išlaikè tik la. gùovs 'karvè' (Smoczyński 1982, 226).

7 Tyrime neteikiami nauji pavadinimų etimologijos aiškinimai, remiamasi jau atliktais kitų tyrejų darbais.

8 Baltų ir slavų kalbose įgijo antrinę reikšmę 'karvë. 
1.2. Didžioji karvès pavadinimų dalis priklauso motyvuotosios nominacijos tipui (90 procentų). Leksikografijos šaltinių duomenimis, lietuvių kalbos sistemoje karvè turi gausų sinonimų inventorių. Didžiąią jų dalį sudaro tarminė leksika.

Pirmoji grupé - darybiniai sinonimai, kurie plačiau (t. y. pristatant ju nominacijos rūšis ir priemones) straipsnyje neapžvelgiami ${ }^{9}$. Darybiniai sinonimai yra motyvuoti konotaciškai arba turi konceptualiųjų požymių, nurodančių gyvulio amžių. Tipiška konotacija yra neigiama ${ }^{10}$, nurodanti karvės fizinę būklę (prasta, menka, liesa) ar amžių (sena), pvz.: karvýna 'prasta, menka karvè, kar viznà 'menka, liesa karvë', karvãpalaiké / kárvapalaike 'prasta, menka (sena) karvè' Emociškai teigiama konotacija atsispindi deminutyvinių priesagų variantuose: karvùtè, karvýka ${ }^{11}$, karváite 'dem. karvè. Nesuaugusios karvès amžių reiškiantys darybiniai sinonimai: karviõte 'vidutinè karvë, pùskarvé 'jauna, dar nesuaugusi karvë.'

Antroji grupè - leksiniai sinonimai. Leksikografijos šaltinių duomenimis, karvė turi įvairių sinchroniškai motyvuotų leksinių sinonimų, kurie pagal motyvacijos požymių raišką sudaro tris MMT: deskriptyvųii (70 procentų), komparatyvųii (20 procentų) ir funkcini (10 procentų).

1.2.1. Deskriptyvųi karvès pavadinimų MMT sudaro trys MM: koloratyvusis (45 procentai), akustinis (40 procentų), morfologinis (15 procentų).

Koloratyvusis MM yra itin produktyvus. Pagal konceptualųi plauko spalvos požymį motyvuojamų karvės pavadinimų leksinių motyvatorių (LM) inventorių sudaro įvairūs koloratyvai, pvz.: LM baltas: baltùika; LM juodas: júodé / juodẽe, júodenka, juodile; LM keršas: keršùika; LM margas: margóji, margùté; L M palšas: palšùika; LM širvas: širvùika; LM žalas: žalóji, žalùika.

Akustinis MM karvès pavadinimų onomasiologinėje sistemoje taip pat produktyvus. Karvės pavadinimai motyvuojami pagal konceptualųị garso ${ }^{12}$ požymį. Šis MM gali būti skirstomas į smulkesnes grupeles, pagal:

1) gyvulio skleidžiamo garso požymị: LM garsažodinès kilmès $b \bar{u}: b \tilde{u} b \dot{e}$; LM

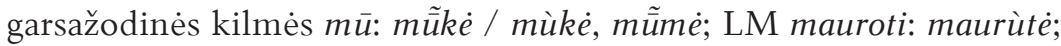

2) gyvulio kvietimo garso požymį: LM garsažodinès kilmès tpru: tprùké;

9 Straipsnyje į darybinius sinonimus kol kas atsižvelgta tik semantiniu požiūriu.

10 „Nesunku pastebèti, kad neigiamas vertinimas kalboje išreikštas dažniau negu teigiamas. Visi aksiologiniai tyrinejjimai patvirtina šią leksinę aksiologinę asimetriją. Matyt, ji turi universalu pobūdị ir remiasi į pragmatišką pasaulio suvokimą: tai, kas gera, teigiama, priimama kaip norma, o tai, kas negera, neigiama, laikoma nukrypimu nuo normos ir todèl labiau diferencijuojama“ (Gudavičius 2009, 188).

11 „Priesaga -yka reta. Galbūt kaip -ikè, kuri žem. tarmèse vartojama žymèti mažybinei formai (kaip -aité, -utè ir kt.)“ (Skardžius 1996, 131).

12 Dažnai tokie karvės pavadinimai yra vaikų kalbos žodžiai. 
3) neaiškios garsažodinès kilmès ${ }^{13}$ pavadinimai: bùzé, bùžé, buzlà, bùčké

Morfologiniam MM priklauso karvès pavadinimai, kurių konceptualusis gyvulio kūno sandaros požymis eksplikuojamas įvairiais daiktavardinès ir būdvardinès kilmès LM, pvz., LM ragas: raguõle, ragùté; LM ilgas ir uodega: ilgauodẽgé; LM kulnas ir šleivas: kulnãšleivè 'kreivakoje karvè'

1.2.2. Komparatyvųi karvès pavadinimų MMT sudaro trys MM: negyvosios gamtos (40 procentų), artefaktinis (30 procentų), zooniminis (30 procentu).

Negyvosios gamtos motyvacijos modeliui priklauso karvès pavadinimai, kurių motyvacijos pamatą sudaro įvairias negyvosios gamtos realijas reiškiantys LM, pvz., LM anglis: anglike 'juoda kaip anglis karvë’; LM dūmai: dùmè 'tamsios spalvos karvë’; LM šalna: šalnkarve 'širma, šerkšna karvë'. Šis MM pagal implicitiškai reiškiamą konceptualųị spalvos požymį papildo deskriptyvųị MMT.

Artefaktinio karvès pavadinimų motyvacijos modelio LM inventorius nèra gausus: LM durklas: dur̃kle 'karvè badiklë' LM raštas: rašỹte 'kerša, marga karvë. Šis MM pagal implicitiškai reiškiamus veiksmo ir spalvos požymius papildo funkcini ir deskriptyvųị MMT.

Zooniminiam karvès pavadinimų motyvacijos modeliui priklauso sudurtiniai pavadinimai, pvz., LM jautis ir karvé: jáutkarve 'riebi, jaučio išvaizdos karvë’ LM ožys ir ragas: ožiarãge 'karvè panašiais į ožio ragais'. Šis MM pagal implicitiškai reiškiamą kūno sandaros požymį papildo deskriptyvųị MMT.

1.2.3. Funkcinị MMT sudaro karvès pavadinimai, motyvuojami pagal konceptualųii veiksmo požymị. Šis MMT gali būti skirstomas ị smulkesnes grupeles pagal:

1) su gyvuliu atliekamo veiksmo (paskirties) požymį, pvz., LM kelti ${ }^{14}$ : kéltu-

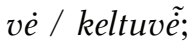

2) gyvulio elgesio, daromo veiksmo požymį, pvz., LM lakstyti: lakstũne 'karvè, kuri vaikosi, ieško jaučių'; LM smaigyti: pãsmaigole 'visur lendanti, dažnai žalos pridaranti karvë; LM zylioti: zýle 'zyliojanti karvè'

1.2.4. Karvès pavadinimų grupeleje išsiskiria reprodukcines karvès savybes žymintys leksiniai sinonimai, kurie sudaro mišrias MM grupes, turinčias keliems MMT būdingų požymių:

1) formalieji variantai su LM bergždžia 'neturinti jaunklio, nevaisinga':

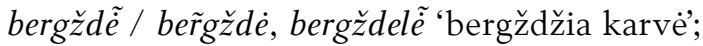

13 Saulius Ambrazas nurodo, kad garsažodinès prigimties kankorèžio pavadinimai, panašūs ị buz-, buž-, buč- šaknis turinčius karvės / veršio pavadinimus, yra būdingi pietų ir vakarų aukštaičių šnektoms (Ambrazas 2010, 95-96).

${ }^{14}$ Motyvacija problemiška, plg. kéltuva 1. 'galvijas, gyvulys'; 2. 'galvijų būrys, banda, galvijai' (LKŽe, DŽe, Sže). 
2) atsivestų jauniklių skaičių nurodantys dūriniai: LM pirmas, antras ir veršis, telis, dèle $e^{15}:$ pirmãveršèe, antrãveršé, pirmãtelè, antrãtelè, pirmadèlẽ / pirmãdèle / pìrmadèlé, antrãdèle / antradèléं;

3) melžimo ar duodamo pieno kiekị, kokybę nurodantys dūriniai: LM kietas, senas ir pienas: kietapienè, senapiẽne. Taip pat dūriniai su LM šaknimis žiem- / žil-ir milžti 'melžti': žiemmilž̃e / žiẽmmilže / žiemmiližè, žilmilž்̃ / žil̃milžè.

1.3. Sinchroninė MM analizė atskleidè, kad karvé pavadinama pagal: spalvos, garso, morfologijos, atliekamos funkcijos ar elgesio, reprodukcijos požymius. Diachroninè (etimologijos) analizė leidžia teigti, kad seniausias karvės motyvacijos požymis yra deskriptyviojo MM tipo, susijęs su raguoto gyvulio vaizdiniu. Svarbiausi iš kalbos sistemos ryškejjantys konceptualieji karvės požymiai - jos amžius ir reprodukcinès savybès: fizinė būklè ir amžius lemia karvès reprodukcijos ir pieno davimo savybes. Tai susiję su pragmatiniu požiūriu $\mathfrak{i}$ aptariamąji gyvuli.

\section{Jaučio pavadinimai}

Sinchroniniu požiūriu lietuvių kalbos jaučio pavadinimai yra dviejų nominacijos tipų: nemotyvuotosios ir motyvuotosios nominacijos.

2.1. Nemotyvuotosios nominacijos tipui priklauso invariantinè leksema jáutis, germanizmas bùlius, lietuvių kalbos sistemoje mažiau prigiję slavizmai biškus, bujôkas / bùjokas.

Lietuvių kalbos sistemoje jáutis - tai 'naminis gyvulys, karvès patinas; kastruotas bulius' (LKŽe), 1. 'karviu patinas, bulius' 2. 'kastruotas karvių patinas' (DŽe). Pagal patekimą i kalbos sistemą jáutis yra vidinès nominacijos būdo leksema. Vytautas Mažiulis apibendrino, kad lie. jáutis yra kilęs iš bl. dial. *jāutja'tas, kuris pajungtas', tai yra fleksijos vedinys iš bl.-sl. *jāuta- '(pa)jungtas ${ }^{16}$ (Mažiulis 1993, 319). Remiantis diachroninių tyrimų rezultatais, senoji motyvacija galètu priklausyti funkciniam MMT: 'tas, kuris pajungtas', t. y. skirtas arti / traukti vežimą (LKŽe: Jáučiai geriau i žagrę tinka kai arkliai Skr; O teip jis art eidavo su arkliu bei su jáučiu, i viena žagrę sukinkytu Klp; Ateis an man’ jaunoja panelè, traukū, vežū jautelis (d.) Ds).

15 Sandas - dèl- pasidarytas iš lietuvių kalbos veiksmažodžio, atitinkančio la. dêt '(ị)siurbti, (i)traukti, sugerti; čiulpti, žįsti’. Šios šaknies varianto *dhē-l- žodžių kitų kalbų etimologiniai

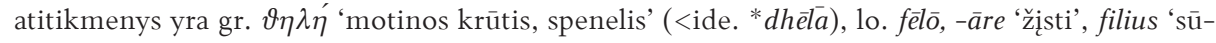
nus', t. y. 'žindantis' (Karaliūnas 2006, 112-113).

16 Lie. jáutis neturi atitikmenų latvių kalboje, tačiau plg. la. jũtis ‘sujungimas' (detaliau žr. Gagliano 2002, 8). 
Išorinès nominacijos būdo leksema bùlius 'karvių patinas' (LKŽe), 'veislinis karvių patinas' (DŽe) vartojama bendrinejje kalboje. Tai skolinys iš vokiečių kalbos (vok. Bulle). Leksemos jáutis ir bùlius skiriasi semantiniu požymiu. Tarp ju susidarę dvejopi santykiai: sinoniminiai ir diferenciniai pagal konceptualųji reprodukcijos požymi (kastruotas / nekastruotas).

2.2. Didžioji dalis jaučio pavadinimų priklauso motyvuotosios nominacijos tipui (80 procentų). Leksikografijos šaltinių duomenimis, lietuvių kalbos sistemoje jautis turi gausų sinonimų inventorių. Didžiąją jų dalį sudaro tarminė leksika.

Pirmoji grupè - darybiniai sinonimai. Semantiniu požiūriu darybiniai sinonimai yra motyvuoti konotaciškai arba turi konceptualiųju požymių, nurodančių aptariamojo gyvulio amžių, dydį. Jaučio jauną amžių arba dydi reiškiantys darybiniai sinonimai: jáutinas 'didelis jautis', jaučiôkas 'ne visai suaugęs, nedidelis jautis', jautùkas 'nedidelis jautis', taip pat ir leksemos bùlius darybinis sinonimas bulìnas 'jaunas bulius, buliukas'. Neigiama konotacija: jáučiapalaikis 'menk. jautis'.

Antroji grupé - leksiniai sinonimai. Leksikografijos šaltinių duomenimis, jautis turi įvairių sinchroniškai motyvuotų leksinių sinonimų, kurie pagal motyvacijos požymių raišką sudaro du MMT: deskriptyvųit (95 procentai) ir funkcinị ( 5 procentai).

2.2.1. Deskriptyvųị jaučio pavadinimų MMT sudaro du MM: koloratyvusis (95 procentai) ir akustinis ( 5 procentai).

Nėra abejonès, kad konceptualusis plauko spalvos požymis yra aktualus ne tik straipsnyje aptariamo gyvulio, bet ir kitų naminių gyvulių pavadinimų nominacijos sistemoje (žr. Šalaviejūtė 2018, 27-46). Koloratyvusis MM yra itin produktyvus - SŽe nurodoma, kad pagal plauko spalvą jaučiai (ir karvès) vadinami: bálnis (balto plauko); balnugãris, baltnugãris; júodis, juodnugãris; dvỹlis, žãlis (tamsiai rusvas); šémis; pálšis (pilkas), dùlis, pilkis; márgis (margas); juodmã̃ois

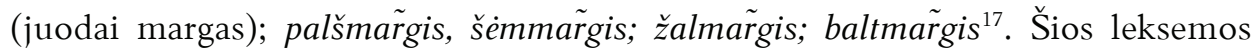
yra substantivum mobile (vyriškosios ir moteriškosios giminès) daiktavardžiai. Semantiniu požiūriu šios leksemos dažnai gali reikšti bet kurị tokios spalvos gyvūną (paprastai galviją): arklị, kumelę, karvę ar jautị, rečiau paukštį. Tik jaučio ir karvès reikšmę turi leksema dvỹlis, $-\dot{e}$ 'dvylas jautis ar karvè'.

17 Tokia leksemų diferenciacija pagal konceptualųji plauko spalvos požymį yra susijusi su auginamų gyvulių veislèmis. Spalva - tai rūšinis požymis, atspindintis hiponiminius leksemų santykius. Dèl substantyvizacijos ir teminès grupès ribų difuziškumo nẻra paprasta nustatyti, ar tai ne okaziniai pavadinimai, kilę iš įvairių epitetų. Šiai problemai spręsti, be abejonès, reikètų pasitelkti ir gyvosios kalbos, tekstynų duomenis, nagrinèti įvairius junginius. Tikètina, kad pavadinimų pagal spalvos požymị, surinktų iš gyvosios kalbos, gali būti ir daugiau. 
Akustinis jaučio pavadinimų MM - neproduktyvus. Konceptualųij garso požymį, reiškiamą LM baubti, liudija tik viena leksema, užfiksuota Jono Basanavičiaus raštuose: baublonnas (LKŽe).

2.2.2. Funkciniam MMT priklauso ne visai aiškios motyvacijos rytų aukštaičių leksema bùkšis. Šios leksemos motyvaciją būtų galima bandyti sieti su rytų aukštaičių plote paliudytu LM bukšéti ‘baksèti, badyti’ (LKŽe).

2.3. Sinchroninė MM analizė atskleide, kad jautis pavadinamas pagal konceptualiuosius spalvos ir garso požymius. Diachroninè (etimologijos) analizė rodo, kad seniausias jaučio motyvacijos požymis yra funkcinio MMT, susijęs su vežimą, arklą traukiančio gyvulio vaizdiniu. Svarbiausias iš kalbos sistemos ryškèjantis konceptualusis jaučio požymis - jo reprodukcinės savybės (kastruotas / nekastruotas).

\section{Veršio pavadinimai}

Sinchroniniu požiūriu veršio pavadinimai yra dviejų nominacijos tipų: nemotyvuotosios ir motyvuotosios nominacijos.

3.1. Nemotyvuotosios nominacijos tipui priklauso invariantinès leksemos ver̃̌sis, têlias, lietuvių kalbos sistemoje neprigijęs slavizmas bišulis.

Lietuvių kalbos sistemoje veřšis - tai 'karvès jauniklis' (LKŽe), 'karvių jauniklis (be lyties skirtumo)' (DŽe). Pagal patekimą ị kalbos sistemą veřšis yra vidinès nominacijos būdo leksema. Algirdas Sabaliauskas apibendrino, kad lie. veřšis yra

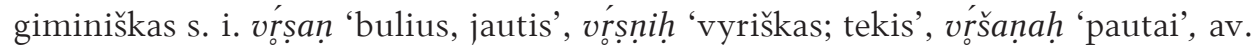
varəšna- 'vyriškas', lo. verrēs 'kuilys, tekis' (Sabaliauskas 1968, 135). Remiantis diachroninių tyrimų rezultatais, semantinẻ leksemos veřšis raida galètų būti: 'patinas' $\rightarrow$ 'bulius' $\rightarrow$ 'jautis' $\rightarrow$ 'jaunas jautis' $\rightarrow$ '(karvès) jauniklis' (Buck 1949, 154-155). Lietuvių kalbos sistemoje reikšmė yra susiaurejusi, tai patvirtina aukštaičių tarmès plote užfiksuotos leksemos veř̌sis reikšmès: '2. karvių patinas, veislinis bulius' (LKŽe), '3. kastruotas darbinis jautis' (LKŽe) ${ }^{18}$.

Leksemos veřšis neutralusis sinonimas - têlias 'karvių jauniklis, veršiukas' (LKŽe). Etimologine lie. têlias motyvacija problemiška. Leksema bendra baltu ir slavų kalboms ${ }^{19}$, jos kilmè aiškinama dviem būdais: 1) siejama su s. i. dhārú‘žindantis', alb. dele 'avis', la. dīle ‘žindantis veršiukas', lie. pirm(a)dèlẽ 'pirmą

18 „Iš semantikos perspektyvos atrodo tikètina, kad pirminė reikšmė buvo 'patinas (bendrai)' (iš *‘apvaisintojas'), ir jo specializacija skirtingiems gyvuliams yra antrinè. Baltu kalbose pirminè reikšmė buvo 'suaugęs jaučių patinas', išlaikyta la. vèrrsis ir lietuvių tarmèse, o lietuvių (daugelyje tarmių) ir prūsų 'mažas jaučių patinas' - antrinè" (Gagliano 2002, 9).

19 Plg. s. r. теля, ukr. теля, 1. cielę, č. tele, bulg. теле́, la. teļš ‘jautelis, veršelis'. 
veršĭ atsivedusi karvè' (Holzer 1983, 343); 2) siejama su ide. *tel- 'kelti, nešti', lo. tollere 'nešti' (Buck 1949, 155).

3.2. Didžioji dalis veršio pavadinimų priklauso motyvuotosios nominacijos tipui (80 procentų). Leksikografijos šaltinių duomenimis, lietuvių kalbos sistemoje veršis turi gausų sinonimų inventorių. Didžiąją jų dalį sudaro tarminė leksika.

Pirmoji - darybinių sinonimų - grupè. Semantiniu požiūriu darybiniai sinonimai yra motyvuoti konotaciškai arba turi konceptualiųjų požymių, nurodančių aptariamojo gyvulio amžių arba dydị, pvz.: veršinas, veršiõkas 'paaugęs veršis', teliôkas '1. paaugęs veršiukas; 2 . karvès jauniklis, veršiukas'. Neigiama konotacija: veřšgalis / veršgalỹs 'menkas veršis', teliõkpalaikis 'prastas teliokas'.

Antroji - leksinių sinonimu - grupè. Leksikografijos šaltinių duomenimis, lietuvių kalbos sistemoje veršis turi kelis sinchroniškai motyvuotus leksinius sinonimus, kurie pagal motyvacijos požymių raišką sudaro du MMT: deskriptyvucii (90 procentu) ir komparatyvuiji (10 procentų).

3.2.1. Deskriptyviajam veršio pavadinimų MMT priklauso akustinis MM. Konceptualųii garso požymį, reiškiamą garsažodinès kilmės LM $m \bar{u}$, liudija rytų aukštaičiu plote užfiksuotos leksemos: mūmùkas, mūmutis, taip pat neaiškios garsažodinès kilmès (plg. Ambrazas 2010, 95-96) rytų ir pietų aukštaičiu pavadinimai: bučiùlis, buziùkas, buziùlis ${ }^{20}$.

3.2.2. Komparatyviajam veršio pavadinimų MMT priklauso zooniminis MM. Konceptualųji lyties požymį, reiškiamą LM karvé, liudija šiaurės žemaičiu leksema karvêlè (LKŽe).

3.3. Sinchroninè $M M$ analizè atskleide, kad veršis pavadinamas pagal skleidžiamo garso ir pagal lyties požymius (neabejotinas ryšys su karvės pavadinimais). Diachroninė (etimologijos) analizė rodo, kad seniausias veršio pavadinimo motyvacijos požymis gali būti susijęs su patino, suaugusio buliaus ar jaučio, apvaisintojo vaizdiniu. Svarbiausi iš kalbos sistemos ryškejjantys konceptualieji veršio požymiai yra jo amžius arba dydis, lytis.

\section{Išva dos}

1. Semasiologiniu aspektu karvès, jaučio, veršio pavadinimai sudaro gausų zoonimu teminès grupès pogrupį: leksikografijos šaltiniuose užfiksuota apie pusantro šimto invariantinių leksemų. Lietuvių kalbos sistemoje bendro hiperonimo aptartoms leksemoms pavadinti nėra. Ši teminė grupe yra difuziška, be aišku ribų. Problemiška nustatyti ribas tarp okazinių, situacinių įvardijimo būdų.

20 Galètų būti mažybiniai variantai pagal karvès pavadinimus mũ $\dot{e}$ / mùkè (LKŽe), $m \tilde{\bar{u}} m \dot{e}$ (LKŽe), bùzé (LKŽe), buzlà (LKŽe). 
2. Onomasiologiniu požiūriu tarp motyvuotojo nominacijos tipo nominatemų daugiausia yra tokių, kurios priklauso deskriptyviajam motyvacijos modeliu tipui, kiek mažiau - komparatyviajam ir funkciniam tipams. Daugiausia pagal skirtingus požymius motyvuotų pavadinimų turi karvè.

3. Motyvacijos modelių sinchroninè analizè leidžia teigti, kad aptariamieji gyvuliai pavadinami pagal įvairius motyvacijos požymius: spalvą (karvẻ ir jautis); skleidžiamą garsą (karvė ir veršis); kūno morfologiją (karvė); reprodukcines savybes, palikuonių atsivedimo skaičių (karvè).

4. Tipinė LM raiška eksplicitinė, jų inventorių sudaro: įvairūs koloratyvai (baltas, juodas, keršas, palšas, širvas, žalas, margas), garsažodinès kilmès veiksmažodžiai (baubti, mauroti), onomatopejjos (bū / bu, mū / mu, tpru), funkciją, elgesi nurodantys veiksmažodžiai (kelti, lakstyti, smaigyti, zylioti), somatizmai (ragas, kulnas, uodega). Implicitinès raiškos LM inventorių sudaro: artefaktų pavadinimai (durklas, raštas), negyvosios gamtos realijos (anglis, dūmai, šalna), zoonimai (jautis, karvè, ožys).

5. Motyvacijos modelių diachroninè analizè atskleidžia, kad seniausi aptariamų gyvulių motyvacijos požymiai yra susiję su 'raguoto gyvulio' (karvè), 'vežimą, arklą traukiančio gyvulio’ (jautis), 'patino’ (veršis) vaizdiniais.

6. Kompleksinè semasiologinė ir onomasiologinè leksemų analizė rodo, kad kalbos sistema fiksuoja labai įvairius karvės, jaučio, veršio konceptualiuosius požymius, iš kurių svarbiausi, ryškiausi yra: a) lytis (patelė / patinas), b) amžius (jauniklis / suaugęs gyvūnas), c) karvès reprodukcinès savybės (neturinti jauniklio / turinti jauniklį), d) karvès ir jaučio plauko spalva. Aptariamų gyvulių hierarchijos viršūnejje yra karvè. Tokia iš kalbos sistemos ryškejjanti kategorizacija atskleidžia antropocentrinị aptartųjų gyvulių vertinimą.

Santrumpos

$$
\begin{aligned}
& \text { alb. - albanų } \\
& \text { av. - Avestos kalba } \\
& \text { bl. dial. - baltų tarminė forma } \\
& \text { bulg. - bulgarų } \\
& \text { č. - čekų } \\
& \text { gr. - graikuc } \\
& \text { ide. - indoeuropiečiuc } \\
& \text { l. - lenkų } \\
& \text { la. - latvių } \\
& \text { lie. - lietuvių } \\
& \text { lo. - lotynų }
\end{aligned}
$$




$$
\begin{aligned}
& \text { pr. - prūsų } \\
& \text { s. i. - senoji indų } \\
& \text { sl. - slavų } \\
& \text { s. r. - senoji rusų } \\
& \text { ukr. - ukrainų } \\
& \text { vok. - vokiečių }
\end{aligned}
$$

\section{Literatūra ir šaltiniai}

Alinei 2005 - Mario Alinei. Names of animals, animals as names: synthesis of a research. In Animal names. Venice: Istituto Veneto di Scienze, 245-268.

Ambrazas 2010 - Saulius Ambrazas. Dèl kankorėžių pavadinimų kilmès. Baltistica XLV (1), 95104.

Buck 1949 - Carl Darling Buck. A dictionary of selected synonyms in the principal Indo-European languages. Chicago: University of Chicago Press.

DŽe - Dabartinés lietuvių kalbos žodynas. Red. S. Keinys. 7-asis patais. ir papild. leid.; elektroninis variantas, 2015 (atnaujinta versija, 2017): http://lkiis.lki.lt.

Gagliano 2002 - Ademollo Gagliano. Le denominazioni del maschio dei bovini in area baltica. Linguistica Baltica X, 7-20.

Gudavičius 2009 - Aloyzas Gudavičius. Etnolingvistika. Šiauliai: Šiaulių universiteto leidykla.

Holzer 1983 - Georg Holzer. Eine indogermanische Lehnwortschicht im Urslavischen und Urbaltischen. WSIA XII, 327-344.

Karaliūnas 2006 - Simas Karaliūnas. Dainava. Vardo reikšmė, kilmė ir istorija. Baltistica XLI (1), $103-117$.

LKŽe - Lietuviu kalbos žodynas. Red. Gertrūda Naktinienė. Vilnius: Lietuvių kalbos institutas, 2008. Prieiga internetu: http://www.lkz.lt.

Lubienė 2015 - Jūratė Lubienè. Lietuviu kalbos mikonimai: nominacija ir motyvacija. Klaipèda: Klaipedos universiteto leidykla.

Mažiulis 1993 - Vytautas Mažiulis. Prūsų kalbos etimologinis žodynas, t. 2. Vilnius: Mokslo ir enciklopedijų leidykla.

Sabaliauskas 1968 - Algirdas Sabaliauskas. Baltų kalbų naminių gyvulių pavadinimai (jų kilmè ir santykis su atitinkamais slavų kalbų pavadinimais). Lietuvių kalbotyros klausimai 10, 101-190.

Skardžius 1996 - Pranas Skardžius. Lietuvių kalbos žodžių daryba. Rinktiniai raštai, t. 1. Vilnius: Mokslo ir enciklopedijų leidykla.

Smetonienè 2018 - Anželika Smetonienè. K. Sirvydo Promptuarium dictionum Polonicarum, Latinarum et Lituanicarum - XVII a. kalbinès situacijos LDK atspindys. Lituanistica, t. 64, nr. 4 (114), 243-254.

Smoczyński 1982 - Wojciech Smoczyński. Indoeuropejskie podstawy słownictwa bałtyckiego. Acta Baltico-Slavica 14, 211-240.

SistŽe - Jonas Paulauskas. Sisteminis lietuvių kalbos žodynas. Vilnius: Mokslas, 1987; elektroninis variantas, 2015: http://lkiis.lki.lt.

SŽe - Antanas Lyberis. Sinonimu žodynas. 2-asis patais. leid. Vilnius: Lietuvių kalbos institutas; elektroninis variantas, 2015: http://lkiis.lki.lt.

Šalaviejūtė 2018 - Žydrūnẻ Šalaviejūtė. Koloratyvusis gyvulių pavadinimų motyvacijos modelis. Res Humanitariae XXIV, 27-46.

Zhabotynska 2010 - Svitlana Zhabotynska. Principles of building conceptual models for thesaurus dictionaries. Cognition, Comunication, Discourse. International online journal 1, 75-92. 


\section{Žydrūnè Šalaviejūtè}

\section{LITHUANIAN ZOONYMS: THE WORDS FOR COW, BULL AND CALF, AND THEIR MOTIVATION}

Summary

From a semasiological point of view, the words for cow, bull and calf form an abundant subset of the zoonym thematic group: about 150 invariant lexemes have been identified from lexicographical sources. The Lithuanian language system does not have a common hyperonym for the lexemes discussed. This thematic group is wide, with no clear boundaries. It is problematic to define the boundaries between occasional, situational naming.

From an onomasiological point of view, most nominathems belong to the descriptive type of models of motivation, and fewer to the comparative and functional types. Cow has the most names according to different attributes of motivation.

A synchronous analysis of motivation showed that animals are named by various motivational attributes: colour (cow and bull); sound (cow and calf); body morphology (cow); reproductive traits, and number of offspring (cow).

The expression of typical lexical motivators is explicit, their inventory consists of: various colouratives (white, black, grey, dark brown, coloured), verbs of a verbal origin (bold, murmur), onomatopoeia (bu, mu, tpru), function, behavioural verbs (raise, scream, spike, squeal), and somatisms (horn, heel, tail). The inventory of implicit lexical motivators includes: artefact names (sword, pattern), inanimate realities (coal, smoke, frost), zoonym (bull, cow, goat).

A diachronic analysis of the motivation showed that the oldest attributes of motivation are related to images of a 〈horned animal〉 (cow), a «carriage, horsedrawn animal〉 (bull), and 〈male〉 (calf).

An analysis of complex semasiological and onomasiological lexemes showed that the language system captures a variety of conceptual features of cow, bull and calf. The most important are: a) gender (female/male), b) age (juvenile/ adult animal), c) reproductive characteristics of the cow (offspring/no offspring). At the top of the animal hierarchy is the cow. This categorisation, which emerges from the language system, reflects the anthropocentric evaluation of the animals discussed. 